\title{
A Federal Referendum: Extending Child Support for Higher Education
}

\author{
Monica Hof Wallace
}

\section{INTRODUCTION}

Child support as a legal obligation has existed for decades. ${ }^{1}$ The principle underlying child support stems from the notion that parents' financial obligation to their children should remain the same even if the parents' relationship dissolves. ${ }^{2}$ The federal government mandated state acceptance of this principle when it required that states adopt guidelines and enforcement principles to ensure equal protection for children of non-intact families. ${ }^{3}$ The notable exception to this principle is parental contribution to higher education.

Today, parents of intact families achieve extraordinary wealth transfer by providing higher education for their children. ${ }^{4}$ This transfer exists almost entirely outside of the traditional child support system. ${ }^{5}$ As a result, the equality principle on which child support is based fails to accommodate children of non-intact families in receiving higher education.

The result proceeds in part from an arbitrary historical event - the lowering of the age of majority in response to a desire to enfranchise the troops fighting during the 1970 s in the Vietnam War. ${ }^{6}$ Ironically, after the age of majority dropped, higher education was extended to a larger percentage of the population ${ }^{7}$ and the traditional family form changed, dramatically increasing the importance of child support. Ultimately, the

Associate Professor of Law, Loyola University New Orleans College of Law. I would like to thank Kate Deumite, Sallie Dupont, and Kathryn Zainey for their invaluable assistance in the research for this Article; June R. Carbone, M. Isabel Medina, Ann L. Estin, and Kathryn Venturatos Lorio for comments on prior drafts; and Dean Brian Bromberger for his support.

1. See Leslie J. Harris et al., Making and Breaking Connections Between Parents' Duty to Support and Right to Control Their Children, 69 OR. L. REV. 689, 692 (1990).

2. Id. at 706-10 (analyzing various principles underlying child support, including the reciprocity between support duties, control rights, and the principle of parental autonomy).

3. See infra note 137-39 and accompanying text.

4. See infra notes 49-54 and accompanying text.

5. See infra notes $49-54$ and accompanying text.

6. See infra notes $28-31$ and accompanying text.

7. See infra section II.B. 
results have been a wholesale extension of a child's financial dependence into the early twenties, and for the children of non-intact families, the lack of support necessary to achieve higher education.

To remedy this problem requires reversion to the basic principle underlying child support - an equality of support for children regardless of the parents' marital status. Today, higher education has surpassed the high school diploma as the pennant of educational necessity, and parents of intact families consistently provide their children with some level of support beyond high school. ${ }^{8}$ To preserve equality for children of nonintact families, legislation is needed to mandate a parental obligation of support for higher education after the age of majority to capture the support that would have been realized had the relationship remained intact.

Scholars have made the case for and against expanding child support obligations to cover post-minority and post-secondary ${ }^{9}$ education in several specific contexts. Some have urged state legislatures to permit highereducation support, while others have challenged post-minority support as unconstitutional. ${ }^{10}$ In response to these debates, some states have expanded child support, either directly or in the form of an educational trust, to cover higher education. ${ }^{11}$ Others, however, have consciously limited support

8. See infra section II.B.

9. The term "post-secondary" is often used interchangeably with the term "post-minority" because the age of majority in most states is eighteen, the age when children are entering college. In some states, however, where the age of majority is twenty-one for child support purposes, "postsecondary" expenses are awarded within the child's minority. Whenever possible, and in attempt to eliminate any confusion, I will refer to "higher-education support" generally, unless the court or commentator uses a particular term.

10. Compare Carol R. Goforth, The Case for Expanding Child Support Obligations to Cover Post-Secondary Educational Expenses, 56 ARK. L. REV. 93, 95-97 (2003) (discussing the changes in the nature of secondary education and how those changes "create a powerful argument in favor of rules which encourage, and potentially require, parents to contribute to the post-secondary education of their children") and Kathleen Conrey Horan, Postminority Support for College Education-A Legally Enforceable Obligation in Divorce Proceedings?, 20 FAM. L.Q. 589, 589 (1987) (focusing "on whether it is appropriate to carve out [an]... exception to the general rule of automatic emancipation for adult children who remain financially dependent by virtue of their status as college students") with Judith G. McMullen, Father (or Mother) Knows Best: An Argument Against Including Post-Majority Educational Expenses in Court-Ordered Child Support, 34 IND. L. REV. 343, 343 (2001) (concluding "that the law should not force divorced parents to contribute to the post-majority education of their children" because "parents of intact families can choose" whether to provide for college expenses) and Vincent A. Cirillo, Curtis v. Kline: The Pennsylvania Supreme Court Declares Act 62 Unconstitutional-A Triumph for Equal Protection Law, 34 DuQ. L. REV. 471, 471-73 (1996) (explaining how a Pennsylvania Supreme Court case declaring a statute requiring college child support unconstitutional "represents a victory for equal protection law"). See generally Scott A. Hall, Note, In the Best Interests of the Child and the State: A Call for Expansion of Iowa's Postsecondary Education Subsidy Law, 57 DRAKE L. REV. 235, 259-60 (2008) (arguing for an expansion of post-secondary education subsidy to apply to married parents).

11. See infra notes 75-89, 221-24 and accompanying text. 
awards for education, providing less protection for children. ${ }^{12}$ Children should enjoy equal opportunity to receive support for higher education no matter the state in which they reside. Indeed, there are definable segments of the population that have the financial resources to assist their children in receiving further education, but for psychological or other reasons, as more fully discussed below, they choose not to do so. Rather than wait for state legislatures to act, if at all, I urge Congress to extend child support obligations to include higher-education expenses.

Valuable empirical evidence highlights the unequal support of higher education for children of divorced families. Judith Wallerstein, in a follow up to her decade-long study on the effects of divorce on children, reported that only twenty-nine percent of children from divorced families receive full or consistent-partial college support from one or both parents, compared to eighty-eight percent of those children from intact families. ${ }^{13}$ Anecdotal evidence also indicates that children of divorce feel less protected economically than children in intact families. ${ }^{14}$ Even fathers with various professional degrees find child support to be the obligation that ends at the child's majority, some stating "I paid my child support through the years. I met all my obligations. I've given my wife thousands of dollars, and now it's up to her."15

Some parents lose concern for the children's welfare because of perceived adverse custodial arrangements or because of animosity for the custodial parent and are determined to avoid any costs beyond the age of majority. ${ }^{16}$ Some parents, understandably so, resent the idea that they are excluded from participating in the decision-making process of higher

12. See infra notes 70-74 (New Hampshire) and 152-57 (Pennsylvania) and accompanying text. In 1997, the Colorado legislature repealed its law that allowed a court to order post-secondary education support without parental agreement. For a discussion of the legislative changes in Colorado, see In re Marriage of Chalat, 112 P.3d 47, 50-51 (Colo. 2005). In North Dakota, the legislature reacted to a court decision that required a father to pay expenses for his child's college education by amending the law to make clear that support cannot extend past majority, unless the child is still in high school. See Larson v. Larson, 694 N.W.2d 13, 16-18 (N.D. 2005) (comparing Donarski v. Donarski, 581 N.W.2d 130 (N.D. 1998) with N.D. CENT. CODE § 14-09-08.2 (1999)).

13. Judith Wallerstein et al., The UneXPeCted Legacy of Divorce: A 25 Year LANDMARK STUDY 335-36 n.6 (2000). Dr. Wallerstein followed sixty families with 131 children going through divorce. $I d$. at 317 . She followed the families one, five, ten, fifteen, and twenty-five years after the divorce and learned a great deal about the long term consequences of divorce. See id. at 247-50, 335-36 n.6; see also JUDITH S. WALLERSTEIN \& SANDRA BLAKESLEE, SECOND CHANCES: MEN, WOMEN, AND CHILDREN A DECADE AFTER DiVORCE 157-60 (1989).

14. See infra notes $181-86$ and accompanying text.

15. WALLERSTEIN \& BLAKESLEE, supra note 13 , at 157-60.

16. Curtis v. Kline, 666 A.2d 265, 272 (Pa. 1995) (Montemuro, J., dissenting); see also William V. Fabricius et al., Divorced Parents' Financial Support of Their Children's College Expenses, 41 FAM. CT. REV. 224, 236 (2003) (concluding that a dramatic factor in payment of college expenses is the legal custody arrangement of the child). 
education, but are expected to pay the bill. ${ }^{17}$ Properly crafted legislation can address these concerns while ameliorating the negative effects on a child's higher-education goals.

This Article undertakes a systematic examination of extending the child support obligation to pay for higher-education expenses. A starting point should be an amendment of federal child support legislation to add highereducation expenses as a component of child support, which ultimately must be addressed by all states. With guidance from states that have already mandated this level of support, a comprehensive discussion of the principles to draft effective state legislation will be examined. First, in Part II, I will examine the laws that led to a decline in higher-education support and will track trends affecting the education of children today. In Part III, I will conduct a comprehensive survey of uniform and state laws, both statutory and jurisprudential, that authorize support for higher-education expenses. Part IV will develop my argument that congressional action is necessary and will address constitutional concerns of equal protection and other potential policy arguments that are counter to this proposal. Finally, in Part V, I will conclude.

\section{PAYING FOR EDUCATIONAL EXPENSES}

\section{A. Historical Perspective}

Parental support for higher education is inextricably intertwined with the legal age of majority. Prior to 1970 and dating back to at least 1751, twenty-one was generally accepted as the age of legal majority in America. ${ }^{18}$ Historically, parents were required to provide "necessaries" to their children until they reached the age of majority or otherwise became emancipated. ${ }^{19}$ The earliest interpretation of "necessaries" came in the 1844 case of Middlebury College v. Chandler. ${ }^{20}$ Middlebury College sought payment for tuition, board, and other related educational expenses from a minor, who could bind himself and therefore his father

17. See infra notes 191-94 and accompanying text.

18. Legal Memorandum, Nat'l Ass'n of Secondary Sch. Principals, The Changing Age of Majority (Jan. 1974). The accepted age of majority "grew out of the Act of Parliament of the Province of Massachusetts Bay, which established 21 as the age for performing certain civic duties back in 1751." Id. The majority age of twenty-one, however, dates back "even further in AngloAmerican legal history - at least to 1620 when the age for serving in the English Army had reached this level." Id.

19. Lindsay E. Cohen, Note, Daddy, Will You Buy Me a College Education? Children of Divorce and the Constitutional Implications of Noncustodial Parents Providing for Higher Education, 66 Mo. L. REV. 187, 189 (2001).

20. 16 Vt. 683 (1844). 
for the payment of necessaries. ${ }^{21}$ The Vermont Supreme Court concluded that although a "good common school education" was essential to one's usefulness in society, a college education was not. ${ }^{22}$

Nearly eighty-five years later, in the 1920s, two decisions framed the debate of whether a parent's obligation of child support extended into college. On the one hand, in Wynn v. Wynn, ${ }^{23}$ the Ohio Court of Appeals rejected the request of a twenty-year-old child to receive support for college from his father, reasoning that the law does not require a parent to send a minor to college, nor does it substitute the court's judgment for that of the parent in deciding whether to send a minor child to college. ${ }^{24}$ On the other hand, the Washington Supreme Court in Esteb v. Esteb ${ }^{25}$ ordered a father to provide support for his daughter's college education, finding that without a college education, a child would be severely restrained from pursuing most trades and professions because he would be forced to compete against people who possessed greater skills as a result of such higher education. ${ }^{26}$ The court rejected the Middlebury College analysis, finding its rule antiquated, and expressed that courts should progress with the changing educational needs of society. ${ }^{27}$

The 1970s saw the greatest upheaval in parental support obligations due to the changing age of majority as a direct result of the Vietnam War. $^{28}$ Eighteen-year-olds were being drafted and dying in Vietnam, but were unable to vote for the politicians deploying them overseas. ${ }^{29}$ In response to public outcry, Congress proposed and the states successfully ratified the Twenty-Sixth Amendment to the U.S. Constitution, lowering the legal voting age to eighteen. ${ }^{30}$

Changes in the voting age, however, called into question the age of legal emancipation. Consequently, in the early 1970s, most states reduced the legal age of majority to meet the legal voting age. ${ }^{31}$ This

1. Id. at 685

22. $I d$. at 686 .

23. 6 Ohio Law Abs. 450 (Ohio Ct. App. 1928).

24. Id. at 451.

25. 244 P. 264 (Wash. 1926).

26. Id. at $267-68$.

27. Id. at 267 .

28. See Horan, supra note 10, at 590.

29. Id.

30. U.S. CONST. amend. XXVI, § 1; see also Kenneth J. Guido, Jr., Student Voting and Residency Qualifications: The Aftermath of the Twenty-Sixth Amendment, 47 N.Y.U. L. REV. 32, 38-44 (1972) (providing a general discussion of Title III of the Voting Rights Act of 1970 and the Twenty-Sixth Amendment's legislative history).

31. Homer H. Clark, JR., The Law of Domestic Relations in the United States $\S 8.1$, at 309 (2d ed. 1988); see also Horan, supra note 10, at 590. Just prior to the amendment, "[i]n 1970, 
change, as expected, had ramifications in family law. States were promptly met with pressing challenges as to how the changes in the age of majority would affect support for children. ${ }^{32}$ Suddenly, some children were legally catapulted into majority, and child support was virtually eliminated for the college years. ${ }^{33}$

At the time, there were no state statutes to deal with this new gap in family law. Some courts denied support after the age of eighteen because they had no authority to enforce care of a child who had reached the age of majority. ${ }^{34}$ As a result, support ended for some children before the completion of high school. ${ }^{35}$ State legislatures reacted and today most states allow child support to continue past the age of eighteen for the limited purpose of permitting the child to graduate from high school. ${ }^{36}$ Now, almost forty years later, a growing trend toward higher education has resulted in college replacing high school as the educational norm, but without the legal obligation of support.

\section{B. Trends in Higher Education}

Although higher education was traditionally attainable only by an elite few, courts have recognized that " $[w]$ here the college graduate ... was [once] the exception, to-day such a person may almost be said to be the rule." ${ }^{37}$ Indeed, a young adult who is unable to secure some form of higher education is "generally handicapped in pursuing most of the trades or professions of life." ${ }^{38}$ Today, a high-school diploma can guarantee no more than a minimum-wage job. ${ }^{39}$ Although overall wages

Montana and Alaska reduced the age of majority to 19." Legal Memorandum, Nat'l Ass'n of Secondary Sch. Principals, supra note 18. One year later, eight states lowered the age to eighteen. Id. "In 1972, twenty more states reduced the age to 18, and two more to 19." Id. In 1973, eleven states reduced the age of majority to 18, including Montana and Iowa, lowering it from 19. Id. Still, "[s]ome states have preferred to confer specific privileges upon youth at various ages rather than change the age of majority itself." Id.

32. Horan, supra note 10 , at 590 .

33. Id. at $590-91$.

34. Id. at 591, 608; see also Shoaf v. Shoaf, 192 S.E.2d 299, 303 (N.C. 1972).

35. Horan, supra note 10 , at 591 .

36. McMullen, supra note 10, at 348 (citing Leslie J. HARRIS \& LeE E. TeItelbaum, FAMILY LAW 600 (2d ed. 2000)).

37. Esteb v. Esteb, 244 P. 264, 267 (Wash. 1926); see also Goforth, supra note 10, at 95 ("The very nature of education in this country has changed radically over time.").

38. Esteb, 244 P. at 267.

39. See Katherine S. Newman, No Shame in My Game: The Working Poor in the InNer CiTY 43 (1999). In this noteworthy study published in 1999, anthropologist Katherine S. Newman examined the lifestyles of 300 people who had graduated from high school, worked minimum wage jobs, and were still struggling due to lack of further education. Id. at xvi. One man she interviewed explained that "a basic education is almost obsolete," and even with a high school diploma, "you 
have been rising, wages for workers without a college degree have been declining. ${ }^{40}$ No scholar, court, or commentator has denied the value of post-secondary education.

Statistics provided by the Department of Education obviate the need for higher education and the rising cost to meet those needs. Increases in enrollment at degree-granting post-secondary institutions have ballooned eight times over the last fifty years and are projected to increase another eleven percent in the next ten years. ${ }^{41}$ The average annual cost per student at a four-year in-state public undergraduate institution, including tuition, room, and board in 2006 was approximately $\$ 12,797$, up from $\$ 1935$ in $1976 .{ }^{42}$ Without room and board, tuition alone increased from $\$ 617$ in 1976 to $\$ 5666$ in $2006 .{ }^{43}$

Increased costs bring challenges to many families. Students generally rely on financial aid, consisting of grants and loans, to attend a post-secondary school, but a gap still exists to cover the full cost of education. The Department of Education refers to this gap as the "net access price," which it defines as the estimate of the cash outlay that students and their families provide in a given year to cover tuition, fees, books, materials, and living expenses. ${ }^{44}$ During the 2003-2004 academic year, the net access price for a four-year public institution was $\$ 9300$, or sixty-one percent of the total cost of attending the institution. ${ }^{45}$ While the government provides significant financial aid, students and their families - and often the custodial parent - shoulder the financial burden of higher education. Fortunately, though, advanced education translates to increased earning power.

"Completion of higher education today is unquestionably tied to financial stability and independence. In fact, 'few people would refute this causal relationship between higher educational attainment and

may as well stay at Burger Barn, 'cause that's as far as you gonna go unless you get lucky and know somebody." Id. at 139.

40. Goforth, supra note 10, at 94 .

41. Thomas D. SNyder et Al., U.S. Dep'T OF Educ., NAT'L Ctr. FOR Educ. Statistics, Digest OF EDUCATION STATISTICS 2008, 502-03, tbl. 331 (2009), http://nces.ed.gov/pubs 2009/2009020.pdf. In 1950, when the federal government entered the child support foray, approximately 2.2 million students were enrolled in degree-granting post-secondary institutions. Id. at 306 , tbl. 188 . In 2006 , the number grew to approximately 17.8 million students and is expected to increase to between 19 and 20 million students by 2017. WiLliam J. HuSSAR \& TABITHA M. BAILEY, U.S. DeP'T OF Educ., NAT'L CTR. FOR EduC. Statistics, Projections of EdUCATION STATISTics TO 2017, 53, tbl. 10 (36th ed. 2008), http://nces.ed.gov/pubs2008/2008078.pdf.

42. SNYDER ET AL., supra note 41, at 503, tbl. 331.

43. Id. (for public in-state, four-year institutions).

44. Michael Planty et al., U.S. Dep'T of Educ., Nat'L Ctr. For Educ. Statistics, The CONDITION OF EDUCATION 2007, 90 (2007), http://nces.ed.gov/pubs2007/2007064.pdf.

45. Id. at 91 
earning power." 44 To obtain a job capable of funding a middle class standard of living, technical training, trade school, college, and even post-graduate education are essential. ${ }^{47}$ According to the U.S. Census Bureau, "[a]dults with advanced degrees earn four times more than those with less than a high school diploma." 48 With the modern mainstream attending college, education has become an economic necessity.

The growing importance of higher education was documented in a fascinating article by John Langbein entitled The Twentieth-Century Revolution in Family Wealth Transmission. ${ }^{49}$ Professor Langbein concluded that unlike in earlier times when parents would transfer wealth to their children at death in the form of property, today parents transfer wealth during life in the form of investment in education for the child or "human capital." His thesis is supported by statistics that demonstrate the growing enrollment of higher education, the immense cost of education, and its long-term value. ${ }^{51}$

Professor Langbein aptly noted, "[t] here is no mystery about who has been paying the bill for this vast expansion of education.,"52 Although scholarships, loans, and student income account for some portion of these expenses, parents are the primary investors in their child's education. ${ }^{53}$ He concludes, rather intuitively, that the dividends

46. Michele M. Benedetto, The Key to Successful Independence: State-Funded Post-Secondary Educational Assistance for Emancipated Foster Youth, 23 ST. JOHN's J. LEGAL COMMENT. 383, 392 (2008).

47. McMullen, supra note 10 , at 345 .

48. Press Release, U.S. Census Bureau, One-Third of Young Women Have Bachelor's Degrees (Jan. 10, 2008), http://www.census.gov/Press-Release/www/releases/archives/education/011196.ht $\mathrm{ml}$. In 2006, the average American worker with less than a high-school diploma earned an average of $\$ 20,873$. Id. After earning a high school diploma, earnings increased to $\$ 31,071$; after attending some college, earnings increased to $\$ 34,650$; after attaining a bachelor's degree, earnings increased to $\$ 56,788$; and after earning a master's, professional, or doctoral degree, earnings increased to $\$ 82,320$. U.S. Census Bureau, Mean Earnings of Workers 18 Years and Over, by Educational Attainment, Race, Hispanic Origin, and Sex: 1975 to 2006, tbl. A-3 (2007), http://www.census.gov /population/socdemo/education/cps2007/tabA-3.xls.

49. John H. Langbein, The Twentieth-Century Revolution in Family Wealth Transmission, 86 Mich. L. REV. 722, 730 (1988).

50. Id. at 723 .

51. In 1840 , the overall cost for formal education in the United States was $\$ 9.2$ million. $I d$. at 730. This figure rose to $\$ 289.6$ million in 1900 and had reached $\$ 23.9$ billion by 1959 . Id. Less than thirty years later, the amount had increased tenfold to $\$ 282.1$ billion, which represented $7 \%$ of the gross national product. Id. In 1870 , only $2 \%$ of the population graduated from high school, a figure that increased a century later to $75.6 \%$. Id . at 731. Singling out college enrollments as a percentage of the college age population showed an increase from $12.5 \%$ in 1946 to $31.3 \%$ in 1985 . Id. The percentage of the American population that had completed four or more years of college study likewise increased from $4.6 \%$ in 1940 to nearly $20 \%$ in 1985 . Id.

52. Id. at 732 .

53. Id. 
associated with educated human capital will far outweigh the dollars that parents spend, and could ultimately have left, in the hands of their children. ${ }^{54}$

The rewards of an education correlate not only to earning power, but to increases in productivity, declines in poverty, and greater income equality. Society as a whole will benefit from a more educated society and, for those children whose higher-education potential has been negatively affected by their parents' marital status, society, through its lawmakers, should step in. Some states have already met the call for reform, and others should follow.

\section{Current State OF THE LAW}

Although no uniform provision exists concerning higher-education support, the American Law Institute Principles of the Law of Family Dissolution $^{55}$ and the Uniform Marriage and Divorce $\mathrm{Act}^{56}$ both contemplate educational support for college. While some states have relied on these models to construct statutes addressing educational support, others have developed support provisions through case law.

\section{A. Uniform Laws}

The American Law Institute in section 3.12 of the Principles of the Law of Family Dissolution makes support for college and vocational training, which is termed an important "life opportunity," dependent on both parental resources and the likelihood that such support would have been forthcoming had there been no divorce. ${ }^{57}$ The Institute envisioned that a child should not suffer the loss of "life opportunities" that the parents can provide without undue hardship. ${ }^{58}$ Recognizing that even highly-educated parents underinvest in the education of children who do not reside with them, the Institute fashioned a two-part test: first, a court should consider whether, based on objective criteria, the parent would

54. Id. at 736

55. The American Law Institute, through a careful deliberative process, publishes various Restatements of the Law, suggestions for model acts or reform, and Principles, which express the law as the Institute thinks it should be. The Principles of the Law of Family Dissolution: Analysis and Recommendations were considered from 1989 through 2002 and were then published in 2002.

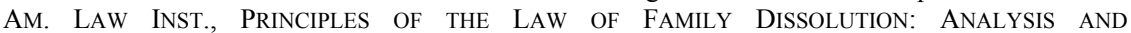
RECOMMENDATIONS XIII (2002) [hereinafter PRINCIPLES].

56. UNIF. MARRIAGE \& DivORCE ACT § 309, 9A U.L.A. 573 (1998).

57. PRINCIPLES, supra note 55, §3.12(1)-(2).

58. Id. 
have provided support if living with the child. ${ }^{59}$ Second, if highereducation support was objectively reasonable, courts should be given discretion in calculating an amount that reflects the parents' ability to pay. ${ }^{60}$ Although several states have adopted the principles embodied in section 3.12, none have adopted the verbiage.

The Uniform Marriage and Divorce Act does not speak directly to college expenses, but it provides that parents owe a duty to a child "to pay an amount reasonable or necessary for his support" after considering five factors: "(1) the financial resources of the child; (2) the financial resources of the custodial parent; (3) the standard of living the child would have enjoyed had the marriage not been dissolved; (4) the physical and emotional condition of the child and his educational needs; and (5) the financial resources and needs of the noncustodial parent." 61 These factors are used by some states to award child support, without authorizing post-majority educational support, ${ }^{62}$ but can likewise extend to college expenses based, as it is for secondary education, on the financial resources of the parents. The Uniform Act also envelops an expectation consideration - "the standard of living the child would have enjoyed had the marriage not been dissolved." 63 Parents who would have expected to pay for college had the relationship remained intact should contribute to higher education should it dissolve.

\section{B. State Laws}

State laws, although not generally modeled on uniform acts, have contributed to an increase in higher-education support, with notable exceptions. Currently, about one-third of states have either a statute or jurisprudence that specifically provides for higher-education support. ${ }^{64}$ Some states that provide for educational support terminate child support at the age of twenty-one, thereby encompassing some post-secondary years. ${ }^{65}$ Only one state prohibits the award of post-minority educational support, even in light of the parties' agreement at divorce to so provide. ${ }^{66}$

\footnotetext{
59. Id. $\$ 3.12$ cmts. a-b.

60. Id. $\S 3.12 \mathrm{cmt}$. b.

61. UNIF. MARRIAGE \& DiVORCE ACT $\S 309$.

62. See, e.g., ARIZ. Rev. Stat. AnN. § 25-320(D) (Supp. 2009); Colo. Rev. Stat. AnN. § 1410-115(2), (15)(b) (West Supp. 2009).

63. UNIF. MARRIAGE \& DiVORCE ACT § 309(3).

64. See infra notes $75-89$ and accompanying text.

65. See infra note 112 and accompanying text.

66. See N.H. REV. StAT. ANN. § 461-A:14(V) (Supp. 2009) (support payments not authorized beyond high school); see also In re Goulart, 965 A.2d 1068, 1071 (N.H. 2009) (concluding that the
} 
The majority of states, even though no post-minority support is authorized by statute, will honor the parties' agreement to provide that support in a contract or in the divorce decree. ${ }^{67}$

Overall, higher-education support can be seen on a continuum with Hawaii providing the most liberal support scheme and New Hampshire providing the most restrictive. In Hawaii, a court can award support for an adult or minor child to pursue an education as long as the child is enrolled as a full-time student or has been accepted and plans to attend as a full-time student in a post high school university, college, or vocational school. ${ }^{68}$ No time limit is placed on that right. ${ }^{69}$

In New Hampshire, however, the legislature statutorily prohibits higher-education support: "No child support order shall require a parent to contribute to an adult child's college expenses or other educational expenses beyond the completion of high school." the New Hampshire Supreme Court, based on the above quoted statute, refused to enforce a provision in a stipulated parenting plan that required the noncustodial father to contribute to the adult child's college expenses. ${ }^{71}$ The facts of the case are particularly troublesome because in the parenting plan, the parties specifically recognized the limiting statutory provision and agreed, with the assistance of counsel, to provide support for college nevertheless. ${ }^{72}$ The court recognized the inequity but felt constrained by the legislation to deny support. ${ }^{73}$ Rather, it urged the legislature to rectify the problem. ${ }^{74}$

Of the other states on the continuum that specifically authorize higher-education support, there are varying degrees of liberality.

statute deprives any state court of subject matter jurisdiction "to either approve or enforce a provision in a stipulated parenting plan that requires parents to contribute to their adult child's college expenses").

67. See infra note 121

68. HAW. Rev. Stat. ANN. § 580-47(a) (West 2008) (providing that in the case of an adult child's education, the state agency, three months prior to the adult child's nineteenth birthday, must send notice to the child and the parent that prospective child support will be suspended unless proof is provided, prior to the child's nineteenth birthday, that "the child is presently enrolled as a full-time student in school or has been accepted into and plans to attend as a full-time student for the next semester a post-high school university, college, or vocational school").

69. See id. In several sections, without limitations on age, educational support for adult children is specifically sanctioned. $I d$. $\S \S 580-47,584-15(\mathrm{e}), 584-18(\mathrm{~b})$.

70. N.H. Rev. Stat. ANN. § 461-A:14(V). For a discussion of the history leading up to the legislative amendment, see Ryan C. Leonard, New Hampshire Got it Right: Statutes, Case Law and Related Issues Involving Post-Secondary Education Payments and Divorced Parents, 4 PIERCE L. REV. 505 (2006).

71. See In re Goulart, 965 A.2d at 1071.

72. Id. at 1069 .

73. Id. at 1072 .

74. Id. 
Connecticut, ${ }^{75}$ Illinois, ${ }^{76}$ Indiana, ${ }^{77}$ Iowa,${ }^{78}$ Massachusetts, ${ }^{79}$ Missouri, ${ }^{80}$ New Jersey, ${ }^{81}$ New York, ${ }^{82}$ Oregon, ${ }^{83}$ Utah, ${ }^{84}$ and Washington ${ }^{85}$ have enacted statutes, and Alabama, ${ }^{86}$ the District of Columbia, ${ }^{87}$ Mississippi ${ }^{88}$ and South Carolina ${ }^{89}$ rely on precedent to permit highereducation support.

Overall, the financial resources of the parents and the child are central concerns for each state. Additionally, the child's commitment to and aptitude for higher education enters the analysis. Notice of the intent to start school and disclosure of grade and course study are, in some states, important, and others consider the standard of living and expectation of the parties during the marriage to award educational support. Because no uniform provision has emerged, a look at court considerations, the duties imposed on parents and children, and the limitations placed on educational support provide a backdrop for discussion.

\section{Court Considerations}

An introspective approach fuels the courts' consideration of highereducation support based in large part on the dependent relationship between a parent and child. Embodied in the factors is the idea that financially competent parents should contribute to the cost of the child's higher education, because if the relationship was intact, support for

75. CONN. Gen. STAT. ANN. § 46b-56c (West 2009).

76. 750 Ill. COMP. StAT. ANN. 5/513 (West 2009).

77. IND. CODE ANN. $\S \S 31-14-11-18,31-16-6-2$ (West 2008).

78. IOWA CODE ANN. $\S \S 598.1(8), 598.21 \mathrm{~F}$ (West $2001 \&$ Supp. 2009).

79. MASS. GEN. LAWS ANN. ch. 208, § 28 (West 2007).

80. Mo. REV. STAT. § 452.340(5) (2000).

81. N.J. StAT. ANN. § 2A:34-23 (West Supp. 2009); see also Kiken v. Kiken, 694 A.2d 557, 560-61 (N.J. 1997) (noting that the legislature "essentially approved" the criteria set forth in previous cases to guide courts in determining a separated parent's obligation to provide support for a child's post-secondary education).

82. N.Y. FAM. CT. ACT $\S 413(1)(c)(7)$ (McKinney 2008).

83. OR. Rev. Stat. AnN. $§ 107.108$ (West Supp. 2009).

84. UTAH CODE ANN. § 15-2-1 (West 2004).

85. WASH. REV. CODE ANN. § 26.19.090 (West 2005).

86. Ex parte Bayliss, 550 So. 2d 986, 994-95 (Ala. 1989).

87. Butler v. Butler, 496 A.2d 621, 622 (D.C. 1985).

88. Nichols v. Tedder, 547 So. 2d 766, 769 (Miss. 1989) (finding that parents may be ordered to pay additional amounts over and above child support for additional expenses such as a college education); see also MISS. CODE ANN. § 93-11-65 (West Supp. 2009) (support terminates at the age of 21).

89. Risinger v. Risinger, 253 S.E.2d 652, 652-53 (S.C. 1979); Lacke v. Lacke, 608 S.E.2d 147, 149-51 (S.C. Ct. App. 2005). 
higher education in most cases would have continued until the child became self-sustaining.

Although "all relevant factors" should be considered, ${ }^{90}$ when analyzing educational support specifically, courts are directed to focus on (1) the financial resources of both parents; ${ }^{91}$ (2) the financial resources and needs of the child $;^{92}$ (3) the expectation of the parties had the marriage remained intact; ${ }^{93}$ and (4) the child's academic prospects, desires, and aptitude. ${ }^{94}$

In several states, courts are also directed to consider the educational background of the parents and how it affects the expectation of the child. $^{95}$ Additionally, when considering the financial resources of the child, some states include income earned during the school year as well as financial aid awarded in the form of grants and loans. ${ }^{96}$ In South

90. New York law is the most general, allowing courts to award support for post-secondary education with "regard for the circumstances of the case and of the respective parties and in the best interests of the child, and as justice requires ...." N.Y. FAM. Cт. АСТ § 413(1)(c)(7) (McKinney 2008); see also Paccione v. Paccione, 870 N.Y.S.2d 430, 433 (N.Y. App. Div. 2008) ("[T]he court may direct a parent to contribute to a child's education, even in the absence of special circumstances or a voluntary agreement of the parties ... [and] must consider the circumstances of the case, the circumstances of the respective parties, the best interests of the children, and the requirements of justice." (citations omitted)).

91. Conn. Gen. Stat. AnN. § 46b-56c(c)(1) (West 2009); 750 Ill. Comp. Stat. Ann. 5/513(b)(1) (West 2009); IND. CodE ANN. § 31-16-6-2(a)(1)(C) (West 2008); IOWA CodE ANN. § 598.21F(2) (West Supp. 2009); WASH. REV. CODE ANN. § 26.19.090(2) (West 2005); Ex parte Bayliss, 550 So. 2d 986, 987 (Ala. 1989); Evans v. Evans, 994 So. 2d 765, 771 (Miss. 2008); Newburgh v. Arrigo, 443 A.2d 1031, 1038 (N.J. 1982); Risinger, 253 S.E.2d at 654.

92. Conn. Gen. Stat. AnN. § 46b-56c(c)(2); 750 Ill. Comp. Stat. AnN. 5/513(b)(3); Ind. CODE ANN. § 31-16-6-2(a)(1)(B); IOwA CODE ANN. § 598.21F(2); N.J. STAT. ANN. § 2A:3423(a)(1), (7) (West 2009); WASH. ReV. CODE ANN. § 26.19.090(2); Bayliss, 550 So. 2d at 987; Newburgh, 443 A.2d at 1038-39.

93. Conn. Gen. Stat. AnN. § 46b-56c(c) (whether it is more likely than not that the parents would have provided support to the child had the marriage remained intact is a threshold question in Connecticut); 750 ILL. COMP. STAT. ANN. 5/513(b)(2) ("The standard of living the child would have enjoyed had the marriage not been dissolved" is considered along with the other relevant factors listed.); WASH. REV. CODE ANN. § 26.19.090(2) (the statute lists both "the expectations of the parties for their children when the parents were together" and specifically "the amount and type of support that the child would have been afforded if the parents had stayed together" as factors to consider); Bayliss, 550 So. 2d at 987 ("the standard of living that the child would have enjoyed if the marriage had not been dissolved" is considered after the first, second, and fourth considerations listed above); Newburgh, 443 A.2d at 1038 ("whether the parent, if still living with the child, would have contributed toward the cost of higher education" is the first factor listed).

94. Conn. Gen. Stat. AnN. § 46b-56c(c)(5); 750 Ill. Comp. Stat. AnN. 5/513(b)(4); Ind. CODE ANN. § 31-16-6-2(a)(1)(A); IOWA CODE ANN. § 598.21F(2); WASH. Rev. CODE ANN. $\S 26.19 .090(2)$; Bayliss, 550 So. 2d at 987; Evans, 994 So. 2d at 771-72; Newburgh, 443 A.2d at 1038; Risinger, 253 S.E.2d at 653.

95. WASH. REV. CODE ANN. § 26.19.090(2) (considering "the parents' level of education"); Newburgh, 443 A.2d at 1038 (considering "the effect of the background, values and goals of the parent on the reasonableness of the expectation of the child for higher education").

96. CONN. Gen. STAT. ANN. § 46b-56c(c)(3)-(4); InD. CODE ANN. § 31-16-6-2(a)(1)(B); IOWA 
Carolina, the child is required to exhaust all grants and scholarships before receiving an award, unless the parents voluntarily assume the obligation in the divorce decree, in which case the child is not obligated to minimize his or her expenses. ${ }^{97}$ Finally, and often a dispositive consideration, a child must maintain a relationship with the parent, including being responsive to advice and guidance from the parent, for higher-education support to continue. ${ }^{98}$

\section{Duties of the Parents}

The parents' primary duty is to pay the court-ordered award of support. In some cases, both parents pay the child's expenses in proportion to their incomes, ${ }^{99}$ while in others, the custodial parentwhen the child returns for the summer - is not required to pay any higher-education support. ${ }^{100}$ Some states set forth the expenses parents will be held accountable for, including room, board, tuition, transportation, books, fees, medical expenses, medical insurance, and living expenses. ${ }^{101}$ In Iowa, the cost of post-secondary education is limited to the cost of attending an in-state public institution, the award

CODE ANN. § 598.21F(2)(b); Newburgh, 443 A.2d at 1039.

97. Nicholson v. Nicholson, 663 S.E.2d 74, 82-83 (S.C. Ct. App. 2008). If the parents' agreement requires the child to minimize his or her expenses, the court will enforce that agreement. Id.

98. IOWA CODE ANN. $§ 598.21 \mathrm{~F}(4)$ (stating that if the child has publicly disowned the parent or refused to acknowledge the parent, educational support will not be awarded); Bayliss, 550 So. $2 \mathrm{~d}$ at 987 (stating that the court may also consider the child's relationship with his parents and responsiveness to parental advice); Norris v. Pethe, 833 N.E.2d 1024, 1033-35 (Ind. Ct. App. 2005) (concluding that a child's refusal to participate in the parent-child relationship will obviate a parent's obligation to pay college expenses); Hambrick v. Prestwood, 382 So. 2d 474, 477 (Miss. 1980) (considering whether the "behavior toward, and relationship with the [parents], makes the child worthy of the additional effort and financial burden" placed upon that parent); Newburgh, 443 A.2d at 1039 (stating that "the child's relationship to the paying parent, including mutual affection and shared goals as well as responsiveness to parental advice and guidance," is among the factors considered).

99. Jeff Atkinson, Support for a Child's Post-Majority Education, 22 LOY. U. CHI. L.J. 695, 706-07 (1991); see, e.g., In re Marriage of Sreenan, 402 N.E.2d 348, 350-52 (Ill. App. Ct. 1980) (affirming the trial court's holding that "ordered the husband to pay 65 percent of [the education] costs, the wife to pay 23 percent, and each daughter to pay 12 percent.").

100. Atkinson, supra note 99, at 707; see, e.g., In re Marriage of Korte, 549 N.E.2d 906, 910-11 (IIl. App. Ct. 1990) (stating that "[w]hile the contribution of [the custodial parent] may not be capable of strict mathematical calculation, the trial judge could very well find . . . that, in equity, [the custodial parent's] contributions are equivalent" to the dollar amount the other spouse was ordered to pay).

101. CONN. GEN. STAT. ANN. § 46b-56c(f) (providing that the expenses cannot be more than the amount charged by the state university for a full-time, in-state student unless the parents agree otherwise); 750 ILL. COMP. STAT. ANN. 5/513(a)(2) (West 2009) (providing for not only the school year, but also during periods of recess). 
can include only "reasonable costs" for "necessary" expenses, and the amount paid by each parent cannot exceed thirty-three-and-one-third percent of the total cost of the post-secondary education. ${ }^{102}$ Legislation, in some instances, directs that the sums awarded should be payable to the child directly, to the parent, or to the educational institution itself. ${ }^{103}$

\section{Duties of the Child}

In exchange for parental support, children are required to provide notice to the parent of enrollment and achievements at various levels. ${ }^{104}$ Some states require the child to notify the parent in advance of attending a post-secondary school. ${ }^{105}$ In Missouri, the child must be enrolled in an institution "not later than October first following graduation from a secondary school." 106 Once the child is enrolled in the academic or vocational school, many states require the student to remain in good academic standing as defined by the institution at the risk of automatic suspension of payments. ${ }^{107}$ In Connecticut, the child must pursue at least

102. IOWA CODE ANN. $\S 598.21 \mathrm{~F}(2)$ (a), (c). Recognizing that a college education includes social, cultural, and educational experiences outside the classroom, Iowa courts reject limiting "necessary" expenses to tuition, room, board, and books. In re Marriage of Vannausdle, 668 N.W.2d 885, 889 (Iowa 2003). See, e.g., In re Marriage of Goodman, 690 N.W.2d 279, 284 (Iowa 2004) (requiring cash allowances); In re Marriage of Steele, 502 N.W.2d 18, 20 (Iowa Ct. App. 1993) (providing for transportation); In re Marriage of Hull, 491 N.W.2d 177, 178-79 (Iowa Ct. App. 1992) (same). Additionally, any expenses that parents previously agreed to pay constitute "necessary" expenses. See generally In re Goodman, 690 N.W.2d at 284 (sorority dues that parents agreed to pay); In re Marriage of Hankenson, 503 N.W.2d 431, 432 (Iowa Ct. App. 1993) (personal and clothing expenses as agreed to by the parent).

103. Conn. Gen. Stat. AnN. $\S 46 \mathrm{~b}-56 \mathrm{c}(\mathrm{g})$ (stating that payments may also be directed "otherwise as the court determines to be appropriate"); 750 ILl. COMP. STAT. ANN. 5/513(a)(2) (stating that the funds can also be deposited into a special account or trust for the purpose of higher education); IowA CODE ANN. $\S 598.21 \mathrm{~F}(3)$ (stating that payments shall not be made to the custodial parent); WASH. REV. CODE ANN. § 26.19.090(6) (West 2005) (stating that the parents are directed to pay the educational institution directly if feasible).

104. Oregon has the most elaborate notification scheme. The child must give written notice to the parent before the child's eighteenth birthday, and if the child changes schools, the child must also send notice. OR. REV. StAT. ANN. § 107.108(6)(a)(A) (West Supp. 2009). If the child is no longer attending school or if the child has failed to give the parents access to his academic performance, the parents must provide to the child written notice of their intent to stop paying, and after thirty days may stop paying. Id. § $107.108(8)(\mathrm{b})$.

105. HAW. REV. ANN. STAT. $\S \S 580-47$ (a), 584-18 (West 2008) (requiring notice to be given to the child support enforcement agency); OR. REV. STAT. ANN. § 107.108(6)(a)(A) (requiring notice to be given to the parents before the child reaches the age of eighteen).

106. MO. REV. STAT. $§ 452.340(5)$ (2000).

107. CONN. GEN. Stat. AnN. § 46b-56c(e) (stating that a child must maintain good academic standing pursuant to the rules of the institution); IOWA CODE ANN. §598.21F(5) (stating that a child must maintain a cumulative grade point average in the median range); MO. REV. STAT. § 452.340(5) (stating that a child must attain grades sufficient for continued enrollment); WASH. REV. CODE ANN. $\S 26.19 .090$ (3) (stating that a child must remain in good academic standing as defined by the 
one-half of the course load determined by the school to constitute fulltime enrollment. ${ }^{108}$ Several states require the child to permit the supporting parent to have full access to the child's academic transcripts and records. ${ }^{109}$

\section{Limitations}

States are not consistent on the age or event that terminates highereducation support. Three states permit a child to collect highereducation support to the age of twenty-three, ${ }^{110}$ one state permits support to the age of twenty-two, ${ }^{111}$ and five states and the District of Columbia permit support to the age of twenty-one. ${ }^{112}$ Some states with and without age limitations also limit support to achieve an undergraduate degree only. ${ }^{113}$

institution).

108. Conn. Gen. Stat. AnN. § 46b-56c(e); see also Mo. Rev. Stat. § 452.340(5) (A “child who is employed at least fifteen hours per week during the semester may take as few as nine credit hours per semester and remain eligible for child support.").

109. Conn. Gen. Stat. AnN. § 46b-56c(e); 750 Ill. Comp. Stat. Ann. 5/513(a)(2) (West 2009); IOWA CODE ANN. § 598.21F(5) (requiring student to provide parent with transcript); Mo. Rev. Stat. § 452.340(5) (same); Or. Rev. StAT. AnN. § 107.108(6)(a)(B); WASH. Rev. Code ANN. $\S 26.19 .090(4)$.

110. Conn. Gen. Stat. AnN. § 46b-56c(a); Mass. Gen. Laws AnN. ch. 208, § 28 (West 2007); WASH. REV. CODE ANN. § 26.19.090(5).

111. IOWA CODE ANN. § 598.1(8) (2001).

112. D.C. CODE $\S 46-101$ (2005) (age of majority is eighteen, with the exception of any common-law or statutory right to child support); MO. REV. STAT. § 452.340(5) (support for higher education to terminate at the age of twenty-one) (currently pre-filed in the Missouri Legislature is House Bill 1391 that would extend higher-education support until the age of twenty-two, which was the law in Missouri prior to a 2007 amendment that lowered the age to twenty-one); N.Y. FAM. CT. ACT $\S 413(1)(a), 413(1)(c)(7)$ (McKinney 2008) (child support, including post-secondary support, terminates at age twenty-one); OR. REV. STAT. ANN. § 107.108(1)(a)(B) (a "[c]hild attending school" for purposes of continued support must be under twenty-one years of age); UTAH CODE ANN. § 15-2-1 (West 2004) ("courts in divorce actions may order support to age 21"); Butler v. Butler, 496 A.2d 621, 622 (D.C. 1985) ("notwithstanding other provisions of the D.C. Code making a person an adult at age 18, for purposes of child support, a person is considered a child until age 21"); Crow v. Crow, 622 So. 2d 1226, 1230 (Miss. 1993) (absent an express agreement by the parents, a court has no authority to order support for college expenses beyond the age of majority, which in Mississippi is twenty-one).

113. CONN. GEN. STAT. ANN. § 46b-56c(a) (no educational support can be awarded beyond an undergraduate degree); 750 ILl. COMP. STAT. ANN. 5/513(a)(2) (terminating educational expenses "when the child receives a baccalaureate degree"); IOWA CODE ANN. § 598.1(8) (the subsidy is limited to an undergraduate education); MASS. GEN. LAwS ANN. ch. 208, $\S 28$ (costs are not permitted beyond an undergraduate degree); MO. REV. STAT. § 452.340(5) (support continues until the child, meeting certain criteria, completes vocational or higher education or until the child reaches the age of twenty-one, whichever comes first); Risinger v. Risinger, 253 S.E.2d 652, 653 (S.C. 1979) (limiting the award to four years of college). 
Not all states limit educational support by age or attainment of degree. As noted above, Hawaii permits support to be paid to an adult child of any age and for an indefinite time. ${ }^{114}$ Indiana and Alabama permit higher-education support as ordered by the trial court, but without a specific temporal requirement. ${ }^{115}$ Finally, in New Jersey, emancipation is attained by the financial independence of the child, not a specific age, and support has been granted for post-graduate education. ${ }^{116}$

Other limitations exist by state. In Connecticut, if the original divorce decree fails to provide for the educational support of the child or to reserve the issue for consideration at a later date, an educational support order cannot thereafter be awarded. ${ }^{117}$ In Massachusetts, for the child to qualify for higher-education support, he or she must be domiciled in the parent's home ${ }^{118}$ and dependent on the parent for maintenance while enrolled in an undergraduate program. ${ }^{119}$ Finally, in Iowa, post-secondary educational support is limited to children of divorce and does not apply to children of unmarried parents. ${ }^{120}$

The majority of states fall toward the end of the continuum and will enforce higher-education support only when parents have agreed in a contract or in the divorce decree. ${ }^{121}$ While commendable, those

114. HAW. REv. STAT. ANN. § 580-47(a) (West 2008).

115. IND. CODE ANN. § 31-14-11-18(1) (West 2008) (support is permitted "until further order of the court"); Waddell v. Waddell, 904 So. 2d 1275, 1280-81 (Ala. Civ. App. 2004) (concluding that "the trial court must set reasonable limitations on the parent's responsibility for postminority educational support," and an award to last for a "reasonable period of time" lacks sufficient temporal certainty).

116. Dolce v. Dolce, 890 A.2d 361, 364-65 (N.J. Super. Ct. App. Div. 2006) (concluding that emancipation does not occur automatically, by operation of law, simply by reason of the dependent child reaching the age of majority); Ross v. Ross, 400 A.2d 1233, 1237 (N.J. Super. Ct. Ch. Div. 1979) (concluding that daughter would not be emancipated until she finished her law-school education, for which her father was required to pay support).

117. ConN. GEN. Stat. AnN. § 46b-56c(b)(1) (the parents must demonstrate that they "fully understand[ ] the consequences of such waiver" before the court will accept a waiver of the right to seek educational support on behalf of the child).

118. MASS. GEN. LAwS ANN. ch. 208, § 28. In McCarthy v. McCarthy, the son's continued domicile remained with his mother, although he lived in a rented apartment while in college. 633 N.E.2d 405, 408 n.4 (Mass. App. Ct. 1994).

119. MASS. GEN. LAWS ANN. ch. 208, § 28. A child over the age of eighteen but under the age of twenty-one may receive extended support regardless of educational enrollment, as long as the child is domiciled in the parent's home and dependent on the parent for maintenance. Id.

120. Johnson v. Louis, 654 N.W.2d 886, 889-91 (Iowa 2002). The plaintiff challenged the differing treatment under equal protection grounds, but the court found a rational basis for the classification drawn by the legislature. Id. at 890 . The court explained that children of unmarried parents cannot claim the loss of stability like children whose legally recognized parental relationship was taken away from them, and children of married parents enjoy the educational benefit as a quid pro quo. Id. at 891.

121. See Colo. Rev. Stat. § 14-10-115(8)(e) (Supp. 2009); Kan. Stat. AnN. § 60-1610(a)(1) (2008); Ky. Rev. StAT. ANN. § 403.213(3) (West 2005); MonT. CODE ANN. § 40-4-208(4) (2008); 
agreements are not always enforceable. Additionally, custodial parents may feel constrained to forgo support or to agree to a lower level of support for higher education in exchange for custody. ${ }^{122}$

A body of case law exists on whether noncustodial parents can repudiate written agreements to pay for post-secondary education as these agreements get merged into the divorce decree and the court loses jurisdiction to award post-minority support. ${ }^{123}$ For example, in Noble $v$. Fisher, ${ }^{124}$ the court determined that an agreement by the noncustodial father to pay for the children's college expenses after majority could not be enforced as a separate contract action because the agreement was merged into the divorce decree and Idaho law did not provide for postmajority support. ${ }^{125}$ In addition, in Christiansen $v$. Christiansen, ${ }^{126}$ the

Nev. Rev. Stat. ANN. § 125.510(9) (West 2008); N.M. Stat. ANN. § 40-4-7(c) (West 2009); N.D. CENT. Code § 14-09-08.2(2) (2008); OHIO Rev. Code ANN. § 3119.86(a)(1)(b) (West 2009); H.P.A. v. S.C.A., 704 P.2d 205, 210 (Alaska 1985); Solomon v. Findley, 808 P.2d 294, 295 (Ariz. 1991); Van Camp v. Van Camp, 969 S.W.2d 184, 186 (Ark. 1998); Kamper v. Waldon, 112 P.2d 1, 3 (Cal. 1941); Shopa v. DeLaurentis, No. CN91-6188, 1997 WL 878713, at *4 (Del. Fam. Ct. Sept. 16, 1997); Slaton v. Slaton, 428 So. 2d 347, 348 (Fla. Dist. Ct. App. 1983); Norris v. Norris, 642 S.E.2d 34, 35 (Ga. 2007); Rosenbloom v. Bauchat, 654 So. 2d 873, 875 (La. Ct. App. 1995); Weiss v. Brown, 1997 ME 57, ๆ5,691 A.2d 1208, 1210; Corry v. O’Neill, 658 A.2d 1155, 1158 (Md. Ct. Spec. App. 1995); Holmes v. Holmes, 760 N.W.2d 300, 309 (Mich. Ct. App. 2008); O’Donnell v. O’Donnell, 678 N.W.2d 471, 474 (Minn. Ct. App. 2004); Zetterman v. Zetterman, 512 N.W.2d 622, 624-25 (Neb. 1994); Pieper v. Pieper, 368 S.E.2d 422, 424 (N.C. Ct. App. 1988), aff'd, 374 S.E.2d 275 (N.C. 1988); Larson v. Larson, 2005 ND 67, $₫ 12$, 694 N.W.2d 13, 16-17; Kirtley v. Kirtley, 301 P.2d 671, 673 (Okla. 1956); Crispo v. Crispo, 909 A.2d 308, 313 (Pa. Super. Ct. 2006); Molak v. Molak, 639 A.2d 57, 58 (R.I. 1994) (per curiam); Watson-Wojewski v. Wojewski, 2000 SD 132, ฯ43, 617 N.W.2d 666, 674, abrogated on other grounds by Roberts v. Roberts, 2003 SD 75, $\mid 21$, 666 N.W.2d 477, 483 n.11; Hathaway v. Hathaway, 98 S.W.3d 675, 678 (Tenn. Ct. App. 2002); Elfeldt v. Elfeldt, 730 S.W.2d 657, 658 (Tex. 1987); Morancy v. Morancy, 800 A.2d 435, 437 (Vt. 2001); Goldin v. Goldin, 538 S.E.2d 326, 330 (Va. Ct. App. 2000); Shortt v. Damron, 649 S.E.2d 283, 286 (W. Va. 2007); Bliwas v. Bliwas, 178 N.W.2d 35, 37 (Wis. 1970); Witowski v. Roosevelt, 2009 WY 5, ๆ22, 199 P.3d 1072, 1078 (Wyo. 2009). At least one court has enforced payment under a theory of promissory estoppel, even when there was no written agreement by the noncustodial parent to provide support. See Zimmerman v. Zimmerman, 8 Fam. L. Rep. (BNA) 2184 (Jan. 18, 1982).

122. See Nancy Polikoff, Custody and Visitation: Their Relationship to Establishing and Enforcing Support, in 2 IMPROVING CHILD SUPPORT PRACTICE, III 30 (1985) (alleging that mothers accept a bargained-down property settlement or reduced child support award to avoid a custody settlement or joint custody arrangement); Elizabeth S. Scott, Pluralism, Parental Preference, and Child Custody, 80 CAL. L. REv. 615, 645 n.93 (1992) (noting that "[m]any women care more about obtaining custody than do men, and might trade away their claims to support and property to insure getting their children."); but see ELEANOR E. MACCOBY AND ROBERT H. MNOOKIN, DIVIDING THE Child: Social and Legal Dilemmas of Custody 160 (Harv. Univ. Press 1992) (finding no empirical evidence that divorce decrees reflect a tradeoff between custody and money issues).

123. See generally Annotation, Responsibility of Noncustodial Divorced Parent to Pay for, or Contribute to, Costs of Child's College Education, 99 A.L.R.3d 322 (1980) (analyzing "state and federal cases involving the responsibility of a divorced parent who was not given custody over a child of the marriage to pay for, or contribute toward, the college education expenses of such child").

124. 894 P.2d 118 (Idaho 1995).

125. Id. at 123 . The court would permit the child, as a third party beneficiary to the agreement, 
New Mexico court refused to enforce a provision in a marital dissolution agreement that provided money to the child for college after his majority because the trial court had no jurisdiction under New Mexico law to award post-secondary support. ${ }^{127}$

In Arizona, however, the Arizona Supreme Court overruled a longstanding line of cases that refused to enforce the parents' agreement to provide higher-education support after the child reached the age of majority. In Solomon v. Findley, ${ }^{128}$ the court approved the father's agreement to provide educational funds for his daughter through completion of college or until she reached the age of twenty-five, whichever came first. ${ }^{129}$ Years later, when the father failed to provide educational funds for the child after she reached majority, the mother sought to enforce the agreement. ${ }^{130}$ The divorce court denied her relief insisting that it lacked jurisdiction because Arizona does not permit the awarding of support beyond the age of eighteen and because their agreement was merged into the divorce judgment. ${ }^{131}$ The Arizona Supreme Court disagreed and enforced support past the age of majority through a separate contract action. ${ }^{132}$

These cases, as well as many others, underscore the changes in noncustodial parents' desires to support their child's education after divorce. At the time of the divorce - and almost certainly during marriage - the noncustodial parent was prepared to pay for college expenses. As time passed and relationships changed, those expectations changed to the detriment of the aspiring child. Using an agreement's status as a contract or as merged into the court order to render it unenforceable undermines the content of the document, which recognized the parents' agreement to higher-education support. The ability of litigants to repudiate agreements based on procedural or other defenses should not be left to chance. ${ }^{133}$

\footnotetext{
to sue for the unpaid support. $I d$.

126. 666 P.2d 781 (N.M. 1983), superseded by statute, N.M. STAT. ANN. § 40-4-7 (West 2003).

127. Id. at 783 .

128. 808 P.2d 294 (Ariz. 1991) (en banc).

129. Id.

130. Id.

131. Id. at 295 .

132. Id. at 297 ("A contract for child support may be enforced by the divorce court as long as the child is a minor. In this situation, the contract is merged with the divorce decree and enforced by the divorce court. It does not follow, however, that the divorce court may enforce that portion of the contract requiring support after the child reaches majority. In that situation, the parties are left to a suit in contract.").

133. See, e.g., Miller v. Miller, 44,163-CA, p. 4-6 (La. App. 2 Cir. 1/14/09); 1 So. 3d 815, 81819 (finding that a clause in a joint implementation order that father was to "begin setting funds
} 


\section{ENACT FEDERAL LAW TO ACHIEVE SUPPORT FOR HIGHER EDUCATION}

The time has come for the federal government to protect children of divorce or of single family households from the loss of higher-education support. Child support laws were intended to provide equality for children regardless of the parents' marital status, but this equality has been lost in higher education. Although historically matters of child support were left to the authority of the states, Congress's presence in the field of family law has precedent.

During the 1970s, Congress was presented with evidence that some single-parent households did not have child support awards or, if they did, the awards were inadequate or simply unpaid. ${ }^{134}$ Also concerning to Congress was the lack of uniformity, even within a state, on the amount of child support awarded. ${ }^{135}$ As a result, Congress passed legislation to require states to have fixed formulas for calculating child support and required each state to adopt enforcement mechanisms, such as mandatory income withholding and income tax intercepts, to increase collections. ${ }^{136}$

The Family Support Act of 1988 provided the most significant change in child support awards by mandating that each state establish guidelines on which support orders would be based. ${ }^{137}$ The Advisory Panel on Child Support Guidelines explained that the Act was intended "to enhance the adequacy of orders . . by making them more consistent with economic evidence on the cost of child rearing." 138 To assist states in drafting guidelines, the Panel provided recommendations, including that parents should share financial responsibility based on their incomes and that children should share in the standard of living of higher-income parents. ${ }^{139}$

aside" for college expenses was ambiguous as to time and amount and therefore unenforceable).

134. See Deborah H. Bell, Child Support Orders: The Federal-State Partnership - Part I, 69 Miss. L.J. 597, 597-98 (1999). Congress began regulating child support in the 1930s, but more substantial involvement occurred in the 1970s. Id.

135. Id.

136. See generally 42 U.S.C. $\S \S 651-669$ (2006); see also Bell, supra note 134, at 599.

137. 42 U.S.C. $§ 667$ ("Each State, as a condition for having its State plan approved under this part, must establish guidelines for child support award amounts within the State. The guidelines may be established by law or by judicial or administrative action, and shall be reviewed at least once every 4 years to ensure that their application results in the determination of appropriate child support award amounts.").

138. Laura W. Morgan, Child Support Guidelines: Interpretation and Application $\S 1.02[\mathrm{e}] \mathrm{n} .30$ (comments of Dr. Robert Williams, Chairman of the Advisory Panel on Child Support Guidelines).

139. Id. § $1.02[\mathrm{~d}]$ 
In continuing to fulfill the goals of the Family Support Act, Congress could act in one of several ways. ${ }^{140}$ Congress could require states to extend support to cover higher education by amending the Family Support Act, which provides state guidelines for child support awards. ${ }^{141}$ Without supplanting a state's authority to legislate the specifics of higher-education support, Congress could require states, when establishing their guidelines, to provide for some level of post-secondary support absent any agreement between the parents. To maintain eligibility for federal funds, states would have to demonstrate that higher-education support is available past the legal age of majority when certain requirements are met. These requirements would be left to the sole discretion of the states. Congress has consistently placed requirements on the states in the area of child support pursuant to its spending power, ${ }^{142}$ and support for higher education would be a natural corollary.

Currently, federal regulations provide that state guidelines must, at a minimum, consider all of the earnings and income of the noncustodial parent, be based on specific descriptive and numeric criteria, and address how the parents will provide for the children's health-care needs. ${ }^{143}$ The law and regulations could be amended to address payment for the child's post-secondary education. As has been done by the states that already recognize this obligation, each state could allow support based on a more liberal or more selective set of criteria. The specifics would be left to each state.

Allowing Congress to direct higher-education support at the state level is justified. Congress initially required state enforcement of child support to repay public funds and to improve the nonsupport of children by their absent parents. ${ }^{144}$ When Congress required states to adopt substantive standards for child support, it did so to provide uniformity and consistency, and later it encouraged responsible fatherhood and motherhood by requiring enhanced enforcement provisions and paternity

140. I intend to introduce ways in which Congress could affect change in the area of highereducation support. The efficacy and preference of Congress's actions is a topic left for another day.

141. See 42 U.S.C. $\$ 666$

142. Ann Laquer Estin, Sharing Governance: Family Law in Congress and the States, 18 CORNELl J.L. \& PUB. POL'Y 267, 280 (2009) (noting that “[t]here is little question that Congress's extensive involvement in family policy is constitutional under the Spending Clause") [hereinafter Estin, Sharing Governance]; see also Ann Laquer Estin, Federalism and Child Support, 5 VA. J. SOC. POL'Y \& L. 541, 577-81 (1998) for an excellent discussion of the limitations that do and should exist on Congress's commerce power and spending power on matters of family law.

143. 45 C.F.R. $\S 302.56$ (c) (2009).

144. H.R. REP. No. 93-1490, reprinted in 1974 U.S.C.C.A.N. 8133, 8145-46. 
laws. ${ }^{145}$ Through its Agenda for College Affordability, the White House has articulated its goal of making higher education available and affordable for more individuals. ${ }^{146}$ The federal government already directs a great deal of the states' comprehensive child support enforcement system, and requiring parental support for children of nonintact families is another avenue to achieve its goals.

Recognizing that some may argue that mandatory legislation will overstep Congress's power to regulate in the area of family law, ${ }^{147}$ Congress could also pass legislation, as it has done in the paternity context, to "encourage" states to adopt laws to extend child support for higher education. In 1988, Congress adopted $\S 668$, volume 42 of the United States Code which encourages states to "establish and implement a civil procedure for establishing paternity in contested cases." Although no proverbial carrot and stick exists to entice states to comply, this expression of legislative preference may result in more states adopting higher-education support.

As another option, Congress could provide grants to States that authorize continued support for higher education. At this time, Congress has authorized grants for states that administer programs to facilitate access and visitation to children by their noncustodial parents. ${ }^{149}$ Congress could likewise provide grants to state institutions of higher learning, if the state authorizes support for higher education even in the absence of the parents' agreement.

Regardless of Congress's ultimate path, the terms of educational support and its duration should be left to each individual state. Already, several states have articulated considerations and requirements for students and parents to follow. A significant body of case law has developed either establishing support or interpreting statutes that authorize support. States can choose to clearly define the parameters of higher-education support, which may curtail the judiciary's involvement

145. Personal Responsibility and Work Opportunity Reconciliation Act of 1996 (PRWORA), Pub. L. No. 104-193 § 101(1)-(10), 110 Stat. 2105, 2110-12.

146. See "Agenda for College Affordability" discussed infra note 220.

147. The author recognizes that when Congress passed the PRWORA, which was intended to protect children and increase the self-sustainability of welfare recipients, it was challenged as an unconstitutional intrusion into the purely state concern of child support. See Kansas v. United States, 24 F. Supp. 2d 1192, 1197 (D. Kan. 1998), aff'd, 214 F.3d 1196 (10th Cir. 2000). The court concluded that Congress can constitutionally condition federal funds on a state enacting a law as long as it is in the interest of the general welfare. Id.; see also Estin, Sharing Governance, supra note 142 , at $280-81$.

148. 42 U.S.C. $\S 668$ (2006).

149. Id. § $669 \mathrm{~b}$. 
in the family decision-making process. ${ }^{150}$ At this time, even states that permit support only when the parents agree have a wealth of information available to them to craft legislation that meets the needs of their citizenry.

Assuming that Congress possesses the proclivity to act, or at least study the issue, the question that has yet to be directly addressed is whether, from a policy standpoint, parents should be required to support their children past the age of majority? And, if so, should the obligation apply only to parents of non-intact families? The second question implicates constitutional concerns of equal protection and will be addressed first.

\section{A. Constitutional Concerns}

The concern articulated by many when considering support for higher education stems from the Equal Protection Clause. ${ }^{151}$ The challenge surrounds the inequity in treatment given to children of intact families when compared to children of non-intact families. Because children of intact families cannot seek payment for higher education from their parents, they are arguably disadvantaged by laws that allow children of non-intact families to receive that support.

The only state in which a parent has successfully challenged a higher-education support statute on equal protection grounds is Pennsylvania. $^{152}$ In 1995, in Curtis v. Kline, the Pennsylvania Supreme Court applied a rational basis analysis to find Act 62, which authorized courts to order support for college expenses, unconstitutional. ${ }^{153}$ The

150. See Jeffrey A. Muriceak, Comment, Pennsylvania's Legislative Response to Blue v. Blue: Adult Children May See Green, But Do Both Parents and Children Have Reasons to Remain Blue?, 99 DiCK. L. REV. 477, 498 (1995) (arguing that a clear delineation of the rights and responsibilities of both parent and child will limit litigation in private, family decisions).

151. U.S. CONST. amend. XIV, $\S 1$. The constitutional due process right to privacy, including the right to determine support for a child's education, has been raised by commentators as another challenge to higher-education support statutes. See, e.g., Atkinson, supra note 99, at 697-701 (arguing that such measures infringe on a family's right to privacy in making important family decisions); Cirillo, supra note 10, at 488-95 (same).

152. Curtis v. Kline, 666 A.2d 265, 269-70 (Pa. 1995). In the Florida case of Kern v. Kern, the court in dicta questioned whether the law could place on a divorced parent any greater obligation to support a child than without the divorce, noting, "such an interpretation may give rise to valid constitutional infirmities in that the state would have no reasonable grounds to treat the adult children of divorced parents any differently than the adult children of married parents." 360 So. $2 \mathrm{~d}$ 482, 485 (Fla. Dist. Ct. App. 1978).

153. 666 A.2d at 269-70. Act 62 was passed in response to another case from the Pennsylvania Supreme Court, which held that without statutory authority, courts were not permitted to order parents to support their child's post-secondary education. Blue v. Blue, 616 A.2d 628, 632 (Pa. 1992). The Act specifically provided that "a court may order either or both parents who are 
court found that the statute classified, without a rational basis, "young adults according to the marital status of their parents, establishing for one group an action to obtain a benefit enforceable by court order that is not available to the other group." ${ }^{\text {"54 }}$ The court concluded that this classification violated the Equal Protection Clause because no rational reason exists to treat the two sets of children differently and the state cannot selectively empower only children from non-intact families. ${ }^{155}$

The Curtis majority was tempered by a strong dissent, which argued that a denial of equal protection would occur if children of broken marriages were deprived of the economic support that they would normally receive from nuclear families. ${ }^{156}$ According to the dissent, "[i]f the Majority's view prevails, there is no recourse for these children, who will be victimized twice, first by the disruptions, both financial and psychological, of their parents' divorce, and again by the system which is theoretically designed to protect them."

Every other state that has considered an equal protection challenge has concluded that higher-education support for non-intact families is constitutional. ${ }^{158}$ In Childers v. Childers, the Washington Supreme Court overruled an appellate court decision that found no reasonable basis for a distinction between divorced and married parents when supporting their children beyond the age of majority. ${ }^{159}$ The court conceded that imposing an absolute duty on all divorced parents to provide highereducation support might be an unreasonable classification, but the state was only seeking to minimize the disadvantages that affect children of broken homes when the obligation to pay is fair and equitable and will not work a significant hardship on the parents. ${ }^{160}$ In other words, "“[t]he child of divorced parents should be in no worse position than a child from an unbroken home whose parents could be expected to supply a

separated, divorced, unmarried or otherwise subject to an existing support obligation to provide equitably for educational costs of their child whether an application for this support is made before or after the child has reached 18 years of age.” 23 PA. CONS. STAT. § 4327 (1993).

154. Curtis, 666 A.2d at 269.

155. Id. at 269-70.

156. Id. at 272 (Montemuro, J., dissenting).

157. Id. at 274 .

158. See, e.g., Ex parte Bayliss, 550 So. 2d 986, 987 (Ala. 1989); Kujawinski v. Kujawinski, 376 N.E.2d 1382, 1389-90 (Ill. 1978); Neudecker v. Neudecker, 577 N.E.2d 960, 962 (Ind. 1991); Johnson v. Louis, 654 N.W.2d 886, 891 (Iowa 2002); In re Marriage of Vrban, 293 N.W.2d 198, 202 (Iowa 1980); In re Marriage of Kohring, 999 S.W.2d 228, 232-33 (Mo. 1999); In re Marriage of McGinley, 19 P.3d 954, 965 (Or. Ct. App. 2001); Childers v. Childers, 575 P.2d 201, 203 (Wash. 1978) (en banc); see also Cohen, supra note 19, at 196-98 (discussing constitutional challenges to higher education support statutes).

159. Childers, 575 P.2d at 203.

160. Id. at 207. 
college education." 161 Because the noncustodial parent will sometimes not willingly provide what he or she otherwise would have but for the divorce, the state has a compelling interest in protecting that child and mitigating the economic disadvantages of divorce. ${ }^{162}$ Therefore, even if the legislation creates a classification, it is supported by a rational basis. $^{163}$

Although the argument of equal protection continues to be raised, without a litigant being able to articulate a suspect class ${ }^{164}$ or a fundamental right, ${ }^{165}$ the courts are bound to apply rational basis analysis. Because states have a legitimate interest in higher education and assisting economically vulnerable children, any equal protection challenge would likely fail. ${ }^{166}$

\section{B. Policy Concerns}

Without constitutional concerns of equal protection, another concern remains: whether it is good policy to require parents of non-intact families to pay for, or at least subsidize, their children's higher education? There is no absolute legal duty for parents to provide a

161. Id. (quoting Robert M. Washburn, Post-Majority Support: Oh Dad, Poor Dad, 44 TEMP. L.Q. 319, 327 (1971)).

162. Id. at $208-09$.

163. Id. at 209 .

164. In re Marriage of Vrban, 293 N.W.2d 198, 201 (Iowa 1980) (finding no suspect class); In re Marriage of Kohring, 999 S.W.2d 228, 232 (Mo. 1999) (finding no authority that unmarried, divorced, or legally separated parents constitute a suspect class); Childers, 575 P.2d at 209 (finding no suspect classification).

165. Neudecker v. Neudecker, 577 N.E.2d 960, 962 (Ind. 1991) (concluding that fundamental child-rearing rights are not infringed because paying expenses for college is like any other support payments that are corollary to custody); Vrban, 293 N.W.2d at 201 (finding no fundamental right); Kohring, 999 S.W.2d at 232 (finding no fundamental right whether to lend financial support to an adult child); Childers, 575 P.2d at 209 (finding no fundamental right not to provide support for children over the age of eighteen); see also Atkinson, supra note 99, at 699-700 (concluding that the parents' interest in the level of support for a child's education would not be found to be a fundamental right).

166. For a more in-depth discussion of the equal protection jurisprudence in relation to highereducation support, see Cirillo, supra note 10, at 501 (agreeing with a Pennsylvania Supreme Court ruling that a statute requiring divorced parents to pay for their children's education expenses was unconstitutional); Leonard, supra note 70, at 521-26 (discussing equal protection arguments for and against mandating divorced parents to pay for post-secondary education); Cohen, supra note 19, at 201-03 (arguing there is no equal protection violation when noncustodial parents are obligated to contribute toward their children's college education); Hall, supra note 10, at 259-60 (calling for an expansion of Iowa's post-secondary education subsidy to apply to married parents); Dan Huitink, Note, Forced Financial Aid: Two Arguments as to Why Iowa's Law Authorizing Courts to Order Divorced Parents to Pay Postsecondary-Education Subsidies is Unconstitutional, 93 IowA L. Rev. 1423, 1449 (2008) (concluding that Iowa's post-secondary education subsidy statute is unconstitutional). 
college education to their children. ${ }^{167}$ Presumably, married parents who can afford to pay cannot be forced to pay for a child's post-secondary schooling. Although one court, in a tax context, has called that principle into question, ${ }^{168}$ most would concede that children are afforded all rights and obligations at the moment of emancipation. One obligation would include paying for post-majority or post-emancipation education.

Professor Judith McMullen, in a 2001 article, argued against requiring divorced parents to pay for court-ordered post-majority child support because, in her opinion, such a requirement amounts to a form of forced heirship. ${ }^{169}$ "Since parents are almost universally free to disinherit their children, parents should be equally free to refuse to pay for a college education." 170 Professor McMullen uses John Langbein's thesis on family wealth transmission to support her position. ${ }^{171}$ She argues that if "having one's education paid for by one's parents is a form of inheritance," then the same reasons that children can be disinherited likewise apply to the payment of educational expenses. ${ }^{172}$ Specifically, Professor McMullen noted that

a divorced parent may choose not to pay college or other post-majority expenses for children of a former marriage because the parent prefers to spend the resources in other ways, because of the belief that the children have gotten enough support already, because the child's behavior is unacceptable to the parent, or because of a desire to have the child become independent. ${ }^{173}$

Just as a testator may prefer to spend all of his money, or to leave all his property to a surviving spouse rather than to his children, a divorced parent may prefer to devote his current resources to a current spouse or minor children from a subsequent marriage. ${ }^{174}$

This argument raises two problems. First, there is a fundamental policy breakdown when society allows parents to favor children from a second marriage over children from the first. Anecdotally, this Article

167. See Terrance A. Kline, Note, Clifford Trusts and the Parental Duty to Provide a College Education: Braun v. Commissioner, 46 U. PITT. L. Rev. 537, 553 (1985).

168. See Braun v. Comm'r, 48 T.C.M. (P-H) 1116, 1119 (1984) (holding that petitioners, a married couple, "clearly... retained the obligation to provide their children with a college education"); see also Kline, supra note 167, at 540-46 (arguing that the Braun court misread New Jersey law when it imposed a duty on married couples to pay for their children's college education).

169. McMullen, supra note 10, at 343-44.

170. Id. at 344 .

171. Id.

172. Id. at 363 .

173. Id.

174. Id. 
originated during conversations with friends and colleagues who lamented about their children's educational prospects because the noncustodial father was refusing to pay for the child's college education, and was not legally obligated to do so, even though he was doing so, or planned to do so, for children of the second family. If a parent is supporting minor children from a second family, those expenses may affect the parent's ability to pay, but it should not negate the responsibility to that parent's first children. ${ }^{175}$

Second, public policy supports an educated populace, ${ }^{176}$ and parents of non-intact families are less likely to support children than if the family were intact. As noted above, almost ninety percent of children of intact families receive full or consistently partial support for college while a little less than thirty percent of children from divorced families do. ${ }^{177}$ From her countless interviews with children of divorce, Dr. Wallerstein notes, " $[\mathrm{w}]$ hen they reach their eighteenth birthday, many young adults suddenly feel like second class citizens.... Many young people consider the cutoff at age eighteen the worst hit of their parents' divorce." 178

Limiting the obligation of parents to provide higher-education support appears to be causally linked to the downward mobility of children of divorce. ${ }^{179}$ More than half of these children end up in lower socioeconomic strata than their parents. ${ }^{180}$ In one interview, Dr. Wallerstein spoke to Billy, who was ten years old when his parents divorced and twenty years old when he quit college. ${ }^{181}$ His father had not sent the expected tuition check that his mother ultimately paid, but to pay for room and board, Billy had to get a job. ${ }^{182}$ Billy was working

175. See Atkinson, supra note 99, at 707-08 (noting that the existence of a second family should be "a relevant consideration in setting the educational support for" the first family, but should not be controlling).

176. See In re Marriage of Vrban, 293 N.W.2d 198, 202 (Iowa 1980) (higher education is clearly a matter of state interest); In re Marriage of McGinley, 19 P.3d 954, 961 (Or. Ct. App. 2001) (there is a state interest in having a well-educated populace); Childers v. Childers, 575 P.2d 201, 208-09 (Wash. 1978) (en banc) (one of the most important goals of a democratic society is a well-educated population).

177. WALLERSTEIN ET AL., supra note 13, at 335-36 n.6.

178. Id. at $248-49$.

179. Ann Laquer Estin, Love and Obligation: Family Law and the Romance of Economics, 36 WM. \& MARY L. REV. 989, 1072 (1995) (citing Judith S. Wallerstein \& Shauna B. Corbin, FatherChild Relationships After Divorce: Child Support and Educational Opportunity, 20 FAM. L.Q. 109, 122-23 (1986))

180. Id.

181. WALLERSTEIN ET AL., supra note 13, at 246-50.

182. Id. at 247 . 
nights and going to school and became worried about health problems. ${ }^{183}$ He found it hard to keep his grades up with work, and expressed, "if my going to college isn't important to them then it isn't important to me, either." ${ }^{184}$ Billy's father commented in a separate interview that Billy was "off and running" and when asked about helping to pay for college, he said, "I don't think it is a good idea. If Billy chooses to go to college, he'll value it more if he comes up with a way to do it himself." 185 Billy's father and mother were both college educated and both had received financial assistance from their families. ${ }^{186}$

Parents of intact families make enormous sacrifices to pay for, or at least assist in paying for, higher education for their children. ${ }^{187}$ Children from divorced families know that they are disadvantaged after reaching the age of majority, but accept it as a consequence of divorce. ${ }^{188}$ While parents of intact families, even unhappy ones, feel pride when their children attend college, parents of divorce, due to physical or emotional distance, do not enjoy the same emotional connection even though they acknowledge their legal obligation, which ends at eighteen. ${ }^{189}$ "I did all that was required" is a consistent theme. ${ }^{190}$

The type of legal custodial arrangement-an issue over which the child generally has no control - can have significant effects on highereducation support. ${ }^{191}$ The findings from a 2000 study of 368 children of divorce found that fathers with joint legal custody voluntarily contributed more to higher-education support than fathers without. ${ }^{192}$ As the fathers' access to the children increased, so did their support. ${ }^{193}$ Parents can feel disenfranchised from the child due to physical distance between the

\footnotetext{
183. Id. at $247-48$.

184. Id.

185. Id. at 248 .

186. Id.

187. Id. at 249 .

188. Id. at 248-49. Wallerstein notes that "[m]ost universities calculate need based on the income of both parents, but if one, often the father who has more money, is unwilling to contribute, the young person is denied scholarships." Id. at 250; see also Leah duCharme, Note, The Cost of a Higher Education: Post-Minority Child Support in North Dakota, 82 N.D. L. REv. 235, 238 (2006) (noting that even though the federal government does not consider the noncustodial parent's income in assessing a student's financial needs, many private colleges do, which can affect an award from that particular school).

189. WALLERSTEIN ET AL., supra note 13, at 252-53.

190. Id. at 252 .

191. Fabricius et al., supra note 16, at 236. When considering what custodial arrangement is in the best interest of the child, the reasonable preference of the child can be considered if the child is of a sufficient age. Solangel Maldonado, Beyond Economic Fatherhood: Encouraging Divorced Fathers to Parent, 153 U. PA. L. REV. 921, 964-65 n.209 (2005).

192. Fabricius et al., supra note 16, at 227, 236.

193. Id. at 236 .
} 
parents' households or due to emotional scars from the divorce, whether involving the child or not. ${ }^{194}$ The financial consequences on the child, even setting aside the emotional effects, are a function of the divorce and custodial arrangement, not the child. ${ }^{195}$

Even for those noncustodial parents who remain in close contact with their children, they view their obligation as a legal one that has a termination date. Ultimately, the custodial parent is left to shoulder the burden of higher education for the child. ${ }^{196}$ In fact, some children even seem surprised to learn they have the right to ask for support after the legal obligation terminates. ${ }^{197}$ In line with this expected termination of support, a recent study indicates that fewer children of divorce are even applying to the nation's top colleges. ${ }^{198}$

In opposition to mandated higher-education support, Professor McMullen also argues that parents may desire to spend their money elsewhere because their children have received enough support or on the belief that their child should be more independent. ${ }^{199}$ That a child would be self-supporting upon the completion of high school, in light of the current economic necessity of post-secondary education, is unlikely. Although child support generally is tied to emancipation or the age of majority, excepting education makes sense. Parents, during minority, may wish to spend their money elsewhere, but with the joy of having children comes the obligation of supporting them. ${ }^{200}$

194. See id. at 236-37 (describing the reasons that parents might feel disenfranchised).

195. See id. (outlining the ways in which the custodial arrangement affects contributions to college expenses).

196. See Lenore J. Weitzman, The Divorce Revolution 278 (1985) (stating that the major responsibility for older children falls on the custodial mother). In a study she conducted at Stanford, Ms. Weitzman concluded that even though mothers had typically less money than fathers, a larger percentage of mothers contributed to the child's higher-education support. Id. at 279. These mothers are faced with the "double dilemma" of child support terminating when the child's expenses reach an all-time high. Id. at 278. See also Charles F. Willson, Note, But Daddy, Why Can't I Go To College? The Frightening De-Kline of Support For Children's Post-Secondary Education, 37 B.C. L. REV. 1099, 1099-1100 (1996) (recounting a conversation with a custodial mother whose successful physician ex-husband would not honor his promise to help support their daughter for college).

197. See WALLERSTEIN ET AL., supra note 13, at 253 (recounting a conversation the author had with a student who had never thought to ask her father to pay college expenses).

198. Id. (citing D. Lillard and J. Gerner, "Getting to the Ivy League: How Family Composition Affects College Choice" (paper presented at the Annual Meetings of the Population Association of America, New Orleans, 1996)).

199. McMullen, supra note 10 , at 358 .

200. Commonwealth v. Gilmore, 97 Pa. Super. 303, 308 (1929) ("[P]aternal duty involves, in addition to provision for mere physical needs, such instruction and education as may be necessary to fit the child reasonably to support itself and to be an element of strength, rather than one of weakness, in the social fabric of the state."). 
In most cases, the obligation of higher-education support continues altruistically for children of intact families, but there is statistical and anecdotal evidence that children of divorce are economically disadvantaged to their counterparts in intact families after completing high school. ${ }^{201}$ The government need not interfere in the decisionmaking process for intact families because society believes parents can be trusted to act in the child's best interest, but when the parent no longer lives with the child, this belief may no longer be justified. ${ }^{202}$ Emotions and bitterness replace reason that parents in an intact family generally exercise. Just as the law permits rehabilitative alimony to help educate a former spouse to support herself, so too should the law permit educational support for children to achieve that self support. ${ }^{203}$ And, as educational expectations of children have progressed, support should meet that expectation.

This Article does not suggest that children should be given a blank check for their higher education. State legislatures and courts, recognizing the inequity that could result to parents, have fashioned considerations that permit courts to award higher-education support only when and to the extent that parents have the financial ability to pay, ${ }^{204}$ the child has a need for assistance (even considering federal grant and loan assistance), ${ }^{205}$ and the child has an aptitude for the requested education. ${ }^{206}$ In several states, the obligation terminates in the child's early twenties. $^{207}$

An expectation analysis - whether the parents if together would have supported the child during college - can buttress a means-needs analysis to ensure that a parent's privacy interest is protected. If a child's parents discussed during marriage that a child should support himself after high school, a court should honor a parent's decision that self-support by the child would be beneficial even if that parent has the objective ability to pay. Similarly, if the standard of living of the family prior to divorce included the expectation that the children would get merit-based or need-

201. WALLERSTEIN ET AL., supra note 13, at 335-36 n.6; WeITZMAN, supra note 196, at 278-79.

202. Harris et al., supra note 1, at 710 .

203. Susan J. Germanio, Note, When College Begins and Child Support Ends: An Analysis of the Pennsylvania Legislature's Response to Blue v. Blue, 3 WIDENER J. PUB. L. 1109, 1149 (1994).

204. See supra note 91 and accompanying text.

205. See supra note 92,96 and accompanying text.

206. See supra note 94 and accompanying text; see also Rohn v. Thuma, 408 N.E.2d 578, 583 (Ind. Ct. App. 1980) (in determining whether a father must pay private school tuition when a public university was available, the court must weigh the advantages to the child against the increased hardship that would be imposed on the father).

207. See supra notes 110-12 and accompanying text. 
based financial aid because the parents could not afford higher education, then a court could deny higher-education support.

An expectation analysis presents a unique challenge when applied to unmarried parents, but can be addressed by examining the parents' expectations during the relationship. For those cohabiting unmarried couples, the analysis would not change significantly, but for children born outside of a relationship, an expectation analysis might include an objective analysis of expectation based on the parents' station in life. Because of the economic and emotional disadvantages of children born to unmarried parents and the concomitant value in higher education, children of unmarried parents should be treated similarly to children of divorce. $^{208}$

To address any further concerns about parental authority, additional duties and limitations could be statutorily defined. For example, in some states, the child has to remain in good academic standing to receive support. $^{209}$ In one state, the child has to fund at least one-third of his education, and the child can only receive an amount based on the price of in-state tuition, even if the child wishes to attend an Ivy League school. $^{210}$ Putting limiting measures in place at the behest of each individual state could ease concerns of parental autonomy while protecting the educational prospects of the child.

Some have suggested that a reluctance to force parents to pay for post-minority education stems not from devaluing education but from a concern over family dynamics and the use by parents of positive rewards to control their children. ${ }^{211}$ In other words, parents should not be made to pay for a child's education when that child's behavior is unacceptable or if the child has no relationship or receives no guidance from the parents. $^{212}$ Several courts have dealt with this issue and concluded similarly. For example, in Norris v. Pethe, an Indiana court terminated the father's obligation to pay his daughter's college expenses because she repudiated her relationship with her father. ${ }^{213}$ The court explained that children should not be allowed to compel parents to support their

\footnotetext{
208. But see Johnson v. Louis, 654 N.W.2d 886, 889-91 (Iowa 2002) (finding that Iowa's postsecondary education subsidy statute that applies to children of divorce, but not children of unmarried parents, was constitutional under the Equal Protection Clause).

209. See supra note 107 and accompanying text.

210. IOWA CODE ANN. §598.21F(2)(a), (c) (Supp. 2009).

211. Harris et al., supra note 1, at 722 .

212. See McMullen, supra note 10, at 365 ("[I]f a divorced parent is legally obligated to pay for higher education, a child may cut off all contact, reject the parent's value system, and still collect the tuition money.").

213. Norris v. Pethe, 833 N.E.2d 1024, 1035 (Ind. Ct. App. 2005).
} 
educational efforts "unless and until the child demonstrates a minimum amount of respect and consideration for that parent." ${ }^{114}$ In Norris, the daughter rejected attempts by the father to send birthday cards and gifts, attend her after-school activities, and participate in counseling. ${ }^{215}$ The court refused to require the father to "stand with outstretched open wallet" while the child rejected his attempts to establish a relationship. ${ }^{216}$ Children can repudiate parental relationships after reaching the age of majority, but they do so with consequence. ${ }^{217}$ By recognizing reasonable expectations that parents place on a child, parental authority can be preserved in exchange for parental support, even into majority. ${ }^{218}$

Carefully crafted state legislation can capture these concerns of parental autonomy. ${ }^{219}$ Parents may want to terminate support for college when a child fails to meet academic standards or refuses to follow guidance from or maintain a relationship with a parent. While supporting a child through higher education, parents should also be able to support themselves and their new families. Ultimately, if parents are unable to lend financial support for higher education, they should not be required to do so. ${ }^{220}$ Some parents may also share the belief that children

214. Id. at 1034 .

215. Id. at $1033-34$.

216. Id. at 1035.

217. See, e.g., Scales v. Scales, 891 N.E.2d 1116, 1119-20 (Ind. Ct. App. 2008) (finding that mother was not obligated to pay for children's college expenses when they repudiated any relationship with her); McKay v. McKay, 644 N.E.2d 164, 168 (Ind. Ct. App. 1994) (father not required to pay son's college expenses when son steadfastly refused to have any relationship with father despite ongoing efforts to reconcile); Hambrick v. Prestwood, 382 So. 2d 474, 477 (Miss. 1980) (father not required to pay for daughter's college expenses when she had no contact with him for at least six years and did not want to have any contact with him).

218. Harris et al., supra note 1, at 736 ("Conditioning support on the child's behaving reasonably preserves a connection between the support duty and control, but the control is divided between the parent[s] and the court.").

219. In Oregon, parents who are obligated to support their adult children may not condition their support on the child's behavior. See In re Marriage of Smith, 606 P.2d 694, 696-97 (Or. Ct. App. 1980) (concluding that a father was required to support his son in college even though the son refused to visit him).

220. Some have argued that courts should require parents without significant assets or income to borrow the funds for higher education because parents of intact families do so and no less should be expected of non-intact families. See, e.g., James G. O'Donohue, Back to School: The Nearly Unavoidable Responsibility for College Expenses, 149 N.J. L.J. 745, 745 (1997). The Obama Administration has also proposed initiatives, some of which could assist parents in paying for college. See Press Release, White House Office of the Press Secretary, Excerpts of the President's Remarks in Warren, Michigan and Fact Sheet on the American Graduation Initiative (July 14, 2009), http://www.whitehouse.gov/the_press_office/Excerpts-of-the-Presidents-remarks-in-Warren-

Michigan-and-fact-sheet-on-the-American-Graduation-Initiative/. The White House reported that the American Recovery and Reinvestment Act of 2009 "increased Pell Grants by $\$ 500$ to $\$ 5,350$ and created the $\$ 2,500$ American Opportunity Tax Credit for four years of college tuition." Id. As part of the "Agenda for College Affordability," President Obama proposed reforming the student loan program, simplifying the student aid application, expanding opportunities for unemployed workers 
should be required to support themselves through college and no court or legislature should order otherwise. If parents shared this sentiment while together, then courts should be able to consider that belief and even if the parents can pay, deny the request for support. Current state laws so provide.

Support awards for higher education may not resemble the child support guidelines currently in place. Formulaic guidelines would likely be too rigid for the fact intensive approach that states may desire. For example, although non-custodial parents are generally required to pay the custodial parent his or her share of child support, both parents, if the child is living away, might be required to furnish support. Because support could include direct educational expenses or living expenses or both, to whom and by whom support is paid may differ.

Because laws can be drafted to provide higher-education support without sacrificing parental autonomy and because states over the past forty years have proven their efficacy, the worst action would be inaction. Undoubtedly, there is a financial divide between children of intact families and children of non-intact families when facing the costs of higher education. Knowing that this gap exists and that considerations can deflect concerns about parental involvement, Congress should focus on mandating or at the least encouraging support for higher education.

Other alternatives have been suggested and, in some states, have been implemented to increase higher-education support for children. In Louisiana, during a child's minority, a court can award a portion of child support to be placed in trust for the educational needs of the child. ${ }^{221}$ The trust must contain maximum spendthrift restraints, which protects the funds from creditors, and must terminate when the child turns twenty-four, unless the parents agree to a later date. ${ }^{222}$ Likewise, in Tennessee, the court can award an amount above that needed for basic support to be placed in an educational trust for college. ${ }^{223}$ When the resources of a noncustodial parent can provide the necessary funds without hardship to that parent, the Tennessee courts reason that establishing an educational trust for college during the child's minority is a proper element of child support. ${ }^{224}$ Professor McMullen has also

\footnotetext{
to attend community college, expanding the Perkins loan program, and investigating improvements to state 529 plans. Id.

221. La. ReV. StAT. AnN. § 9:315.13(B)(2) (2008).

222. Id.

223. Nash v. Mulle, 846 S.W.2d 803, 806-07 (Tenn. 1993).

224. Id.
} 
suggested offering tax or other incentives to parents who provide highereducation support for their children. ${ }^{225}$

While these alternatives are viable solutions, congressional action is preferable. Educational trusts during minority fail to include children who are in college at the time of divorce and may be reserved for highincome cases only. Immediate tax or other incentives may cause some parents to provide higher-education support, but tax incentives already exist for parents saving in advance for college, most notably the state 529 plans. $^{226}$

\section{CONCLUSION}

Children across this country become self-supporting, but they do so gradually. Support for children in intact families can taper down as they reach factual independence, while support for children of divorce or unmarried parents abruptly ends at the age of legal majority, even though factual independence generally follows. Parents should pay for higher education when they have the means to pay and the child is seeking support because they wish to further their education. When making the choice to have a child, resulting responsibilities are necessarily imposed. "[T]he privilege of parenthood carries with it the duty to assure a necessary education.",227 Today, "necessary education" has taken on new meaning.

Congress can effect considerable change in higher-education support. During the last forty years, some states have protected children from the economic disadvantage of their parents' marital status by permitting support to extend to higher education. Even in the wake of Curtis v. Kline, when the Pennsylvania Supreme Court struck down a higher education support statute based on equal protection, other states

225. McMullen, supra note 10, at 368 .

226. A 529 plan, legally known as a "qualified tuition plan," is "a tax-advantaged savings plan designed to encourage saving for future college costs." U.S. Securities and Exchange Commission, An Introduction to 529 Plans, Aug. 6, 2007, http://www.sec.gov/investor/pubs/intro529.htm. "There are two types of 529 plans: pre-paid tuition plans and college savings plans." Id. "All fifty states and the District of Columbia sponsor at least one type of 529 plan." Id. "Pre-paid tuition plans generally allow college savers to purchase units or credits at participating colleges and universities for future tuition and, in some cases, room and board," while college savings plans "generally permit a college saver ... to establish an account for a student," with several investment options for his or her contributions, for the purpose of paying the student's eligible college expenses. Id. "Investing in a 529 plan may offer college savers special tax benefits;" for example, "[e]arnings in 529 plans are not subject to federal tax, and in most cases, state tax," so long as withdrawals are used for eligible college expenses, such as tuition and room and board. Id.

227. Newburgh v. Arrigo, 443 A.2d 1031, 1038 (N.J. 1982). 
have passed legislation to protect children and confirmed their constitutionality. ${ }^{228}$ There has been no trend to retreat from highereducation support, but currently only sixteen states permit such support.

With knowledge that children of divorce or unmarried parents are emotionally and economically disadvantaged in attending a postsecondary institution, lawmakers have and should continue to intervene to redress this inequity. Statutes can be drafted to mitigate concerns of parental authority and autonomy and children can receive the support that, but for their parents' marital status, would have been forthcoming.

228. 666 A.2d 265, 270 (Pa. 1995). 